April 2009

\title{
Hiding in Full View: The "Forgotten" Bushman Genocides of Namibia
}

Robert J. Gordon

Follow this and additional works at: https://digitalcommons.usf.edu/gsp

\section{Recommended Citation}

Gordon, Robert J. (2009) "Hiding in Full View: The "Forgotten" Bushman Genocides of Namibia," Genocide Studies and Prevention: An International Journal: Vol. 4: Iss. 1: Article 4.

Available at: https://digitalcommons.usf.edu/gsp/vol4/iss1/4

This Articles is brought to you for free and open access by the Open Access Journals at Digital Commons @ University of South Florida. It has been accepted for inclusion in Genocide Studies and Prevention: An International Journal by an authorized editor of Digital Commons @ University of South Florida. For more information, please contact digitalcommons@usf.edu. 


\title{
Hiding in Full View: The "Forgotten"' Bushman Genocides of Namibia
}

\author{
Robert J. Gordon \\ Department of Anthropology, University of Vermont
}

\begin{abstract}
This article examines the Bushman genocide of 1912-1915 which, despite overwhelming evidence of its having occurred, has been largely ignored by both scholars and the local population. It invokes the Durkheimian distinction between necessary and sufficient conditions. Necessary conditions are akin to Marxian notions of "primitive accumulation" or Weberian "booty capitalism," but in addition, the author emphasizes the demographics of the settlers, largely (aspiring) middle-class single men, and suggests that notions of the Rechtsstaat-code-based rather than case-based rule of law-represented an important, if not distinctive, sufficient condition in facilitating genocide, especially in tandem with the legitimation activities of turn-of-the-century scholars. The article concludes with a brief examination of the "bureaucratization" thesis.
\end{abstract}

Keywords: colonial state formation, San, Germans, South Africans, demographics

In 1914, while the numerically superior and better armed South African forces were invading German South West Africa, the seriously outmanned German commander, Major Viktor Franke, had to send a company of sixty Schutztruppe ("protection troops") to the Grootfontein district to deal with troublesome Bushmen. The unpublished journal/memoir of one of these troopers, Gunther Walbaum, provides vivid documentation of what happened on these "Bushman patrols." His commander instructed him as follows: "I would be glad if you will not kill too many [Bushmen] if possible. Only kill them when there is an attack, but use your own discretion."1

The banality of these hunts is obvious from Walbaum's description:

After three kilometers we reached an open field where Jan [the guide] showed us to go down. One kilometer in front of us some Bushmen were busy digging out uintjies [tubers]. Now Jan did not want to walk in front anymore, because he did not want to have anything to do with the shooting. We discussed our next step for a moment so that we could encircle them. We had to sneak up to them like one does with game. On a sign, we all got up with our guns ready to shoot. We were about fifty to seventy meters away from them. The Bushmen stood in astonishment. When we approached them, ten or twelve men ran away. Falckenburg and one of our natives shot two. Unfortunately, I missed. ${ }^{2}$

Indeed, death was often preferable to capture:

Jonas [a prisoner] said he did not know Sus [a farm that had been raided recently by Bushmen], well, he did not want to know Sus, but the women said they saw him as he cut the boy's heart out. [Note: This is not verified by court records.] The people were asked how many people were involved and how many guns they had, as well as who had killed the other [white] farmer. They said nothing. I hit them until the blood was running down [in streams]. They behaved badly and said their brothers would kill us all. I told them I would get them all. At night I tied each one naked to a tree. It was ice cold and they stood far from the fire; they tried to untie themselves with their feet.

Robert J. Gordon, "Hiding in Full View: The 'Forgotten' Bushman Genocides of Namibia." Genocide Studies and Prevention 4, 1 (April 2009): 29-57. (C) 2009 Genocide Studies and Prevention. doi:10.3138/gsp.4.1.29 
The watchman hit them all over with a sjambock [hippo-hide whip]. At four o'clock in the morning — the coldest time of the night—-they started begging: "Mister, if you bring us to the fire we will say everything." I told them that they had to wait because I was sure they were not mistreated enough.

At five o'clock we untied them. Jonas told us everything, but his bad behavior he did not change. The woman stayed near the fire with her child during the night. All the men had bad lacerations on their shoulders from trying to untie themselves by rubbing their shoulders on the bark of the tree.

At eight o'clock we took the scoundrels to the bush where we found the right trees in no time. A few boxes were piled up, ropes were tied onto branches-the men were put on the boxes with their hands tied and ropes placed around their necks. We kicked the boxes over and they were dead in seconds, because their necks were broken. All four of them had burst veins in the lower leg after they died. In twenty minutes they were dead. The women we took to Wiesental [a farm]. ${ }^{3}$

One of the first orders of business of the newly installed South African administration in 1915 was to ban "Bushman hunting." The instructions of the secretary for South-West Africa were explicit:

It is necessary in the interests of all to secure a truce and bring the belligerents back to reason. The farmers must be told that shooting of Bushmen will no longer be permitted and will be prosecuted with all the rigour of the law. The Bushmen must be informed in like manner. ${ }^{4}$

But so traumatic was Bushman experience of German brutality that, three years after the German defeat, the South African military magistrate of Grootfontein felt duty bound to break protocol and write directly to the secretary of the Protectorate. Magistrate Gage described how he encountered some Bushmen prisoners who

were trembling so much that I remarked on it to the Gaoler. Later they were brought before him under an escort with fixed bayonets, and their terror was pitiful to behold.... It is like catching a bird in your hand when you can see its heart throbbing against its breast and you know that unless it is soon released it will die of sheer terror. ${ }^{5}$

Walbaum's acts were not those of a few miscreants; they were systemic.

This article focuses on genocide in Namibia. Not the much-heralded, if problematic, Herero genocide of 1904 , but one that is more invidious because it has effectively been made invisible and forgotten. While German mistreatment of the Herero provoked a public outcry in Germany and Europe and led to large-scale government reforms-moving the colonial apparatus from naked coercion to scientific colonialism, epitomized by the founding of the Colonial Institute in Hamburg in 1908the genocide with which this article is concerned was hardly heeded, apart from one or two isolated voices of protest. Indeed, so successful has this process of "invisibilization" been that even scholars with expertise on those labeled Bushmen or San, when discussing the vulnerability of indigenous peoples to genocide, ignore this earlier history.

Contemporary anthropologists specializing in the $\mathrm{San}^{6}$ have largely overlooked the long history of denigratory academic involvement with those labeled "Bushmen."7 Even genocide scholars specializing in Namibia ignore the Bushman or San case, ostensibly on the grounds that no one has done research on this issue. ${ }^{8}$ Popular histories of the destruction of tribal or indigenous peoples also seem to forget this dark moment. Ironically, nowadays Bushmen themselves do not recall this genocide. $^{9}$ 
This silence might have serious consequences. Recently the prominent and influential Herero historian Dr. Zedekia Ngavirue weighed in on the debate about Herero genocide and the claims for German reparations; he reportedly

\begin{abstract}
dispelled the confusion of "other people" having suffered. He said it is true that the numbers of Namas were reduced with some having been taken to countries like Togo and Cameroon. He said it was equally true that some Damaras were on the side of the Ovaherero and that some Oshiwambo fought on the side of the Ovaherero like Chief Nehale ka Mpingana of Ondonga.
\end{abstract}

However, Ngavirue said the German army only issued the Genocide Order against the Ovaherero, only Ovaherero land was confiscated wholesale and only Ovaherero leaders were hanged. All these, he said, pointed out to a clear German agenda against the Ovaherero.

He said the German government keeps referring to "others" to avoid facing the Ovaherero squarely while purporting to acknowledge the atrocities inflicted on the Ovaherero. ${ }^{10}$

It is not that the Bushman genocide in Namibia was unknown. Indeed, the (in)famous 1918 Blue Book detailing Germany's treatment of the indigenes made much of it. ${ }^{11}$ Lawrence Green, a South African journalist who did much to create the popular settler image of Namibia in his numerous books (which were reprinted many times and carried such romantic titles as Lords of the Last Frontier and Where Men Still Dream) frequently mentioned that Bushmen were shot on sight by the Germans; ${ }^{12}$ American travelers such as Sidney Legendre and Negley Farson aver the same. ${ }^{13}$ German settlers and travelers all acknowledged the genocidal actions. Lydia Höpker, reminiscing about her days as a farmer in the Grootfontein-Otavi area writes of a neigbor, Frau Keller, showing her a Bushman child in her care, the result of a punitive expedition against Bushmen that had killed many and taken numerous prisoners. Höpker includes a photograph of "captured Bushmen" in her book, and writes that "orphaned Bushmen children were divided among German farmers wives who cared for them and later used them as personal servants." ${ }^{14}$ In outer districts, she avers, one could never be certain about one's life when meeting Bushmen, who hid and shot poisoned arrows at both whites and native shepherds; she then goes on to detail numerous instances of settler paranoia concerning Bushman attacks, including an experience of her own when her tea was ostensibly poisoned. Others concurred. ${ }^{15}$

\title{
Ghosts in the Graveyard: Apparitions beyond the Limelight
}

Part of the reason for this invisibilization is precisely the narrow focus on the so-called Herero Genocide, often touted as the "first genocide of the twentieth century" or the "first modern genocide." 16 A closer examination shows that hostilities did not break out in January 1904 and cease in 1907 but started in 1903 and petered out into continuous police action that persisted right up to the South African invasion in 1915. This focus has led to such a single-minded emphasis that events slightly out of focus are ignored. This article is concerned with the turbulent wake or afterglow of the "official war." This is where things get interesting, if not scary.

Once we remove that ethnocentric framing device called "the twentieth century," it is obvious that the "Herero Genocide" had more in common with the late-nineteenthcentury colonial wars of annihilation-such as the Mashonaland wars of 1897 and some of the "Zulu" wars ${ }^{17}$-or even with what was happening contemporaneously in 
the Belgian Congo and with the US invasion of the Philippines, than with the classic defining genocides of the twentieth century. It was a defining moment in Namibian history, however, insofar as it led to the transformation of a "weak" colonial state into a "strong" one, and it was under the latter, with its laws and bureaucrats and pretensions to scientific colonial administration, that the machinery was put in place for implementing genocide against "bandits" and other "forager" groups such as the so-called Bushmen. It was in the context of a Musterstaat ("model state"), as Zimmerer ${ }^{18}$ felicitously calls it, that a lot of the dirty work of genocide got done.

In Germany, some of the major objections to the war had been its high cost to the German taxpayer and its destructive impact on the supply of cheap labor. ${ }^{19}$ Colonies had to be made to pay for themselves, which contributed directly to further exploitation of indigenous peoples. To facilitate this economic self-sufficiency, decisionmaking power gradually devolved from Berlin to the settlers. In 1909 a Landesrat, an advisory body consisting of fifteen elected and fifteen appointed members, was established in Windhoek. The Landesrat had to jointly approve any regulations concerning "Native Affairs." ${ }^{20}$ Horst Drechsler has famously termed the period after the 1904-1907 war the "peace of the graveyard." ${ }^{21}$ Yet, for all the deathly silence of historians on this age, it was a time when many ghosts were abroad. It was a period of economic boom for the settlers. Diamonds were discovered in Luderitzbucht in 1908; the fabulously rich Tsumeb copper mine was expanding, and the completion of railroads leading to the mine made access much easier for settlers and entrepreneurs. Between 1907 and 1911 the settler population almost doubled, from 7,110 to 13,962. ${ }^{22}$ Transfer of resources continued apace. Land placed under settlers' control increased from $4.4 \%$ of total landmass in 1903 to $13 \%$ in 1910. To put it differently, the number of European farms increased from 458 farm units totaling 4.8 million hectares (mil ha) in 1904 to 1,331 farm units totaling 13.4 mil ha in 1913. Settlers were also amassing animal wealth: the number of cattle owned by Europeans increased from 52,531 in 1907 to 205,643 in 1913, while small stock under European ownership increased from 208,480 to $1,011,697 .{ }^{23}$ While farmers and smallholders numbered only 1,390 in 1911, there were also some 2,572 artisans and miners; 1,035 merchants, shopkeepers, and innkeepers; and slightly fewer than 900 civil servants. $^{24}$

Both the mining industry and settlers demanded cheap labor, a rather scarce commodity given the infamous Vernichtigungsbefehl ("annihilation order") issued by Lothar von Trotha in 1904. Indeed Moritz Bonn, a young liberal economist who had gone out to South Africa in 1906 to field-test Hobson's theory of imperialism and subsequently made a three-month trip to explore conditions in Namibia, complained that

though the country has regularly been called a white man's country, most manual work is carried out by native labour... the real problem ... has always been not only how to find the white man to settle the country, but quite as much how to find coloured labourers to support them when settled..$^{25}$

So desperate were settlers for inexpensive labor that larger employers were forced to recruit laborers from South Africa, while efforts to recruit labor from other German colonies failed and importing Chinese and Indian labor was seriously considered. ${ }^{26}$ In such a situation, recruiting labor from Owamboland, an area to the north of the Etosha Game Park, became a major priority. The number of Owambo contract laborers tripled from about 4,000 in 1908 to 11,764 by $1914 .{ }^{27}$ These laborers, however, had to traverse an area inhabited by San or Bushmen. 
The German administration did its utmost to facilitate the "internal" labor supply as well, by way of a series of draconian Verordnungen (ordinances) issued by Governor Friedrich von Lindequist in August 1907, which allowed for indigenous inhabitants to be stripped of their property (largely land and livestock). Once they were deprived of their "traditional livelihood," it was assumed that they would be forced into the colonial workforce. Indigenes had to apply to the governor for permission to own livestock. Another set of regulations sought to control their movements through "pass laws": people were required to wear brass tokens around their necks, a central register of natives was to be developed, and work contracts were regulated. Settlers were given the right to engage in "fatherly chastisement" of their workers. Lastly, and ominously for Bushmen, it was decreed that "natives who are loitering, may be punished as vagrants, when they can show no means of support. ${ }^{28}$ These three sets of regulations locked together in a mutually supporting way to forcibly incorporate indigenous people into the settler-controlled economy. In September 1907, commenting on the Eingeborenen-Verordnungen ("Indigenous Ordinances"), the Windhuker Nachtrichten said,

The native must be made aware that he has a right to exist only in direct dependence on the territorial authorities; without this, he is in a certain sense an outlaw: a livelihood outside of working for whites is not available to him. ${ }^{29}$

Directly and indirectly, this legislation facilitated the genocide of a people whose mode of existence was defined by the state as vagrancy or outlawry.

The bitter reality for settlers was that they were faced with a critical labor crisis of their own making and had to make do with Bushman labor, no matter how unsatisfactory they alleged it to be. By 1908 police and military patrols were rounding up Bushmen and allocating them to farmers as laborers. The mines also required labor: a military patrol from the Waterberg rounded up some fifty Bushmen in the vicinity of Tsumeb and transferred them to the mines as laborers. ${ }^{30}$ In 1910 , the Outjo District Council decided that all Bushmen in the district should report for work, and, ultimately, police succeeded in rounding up more than $100 .{ }^{31}$ Of the 2,829 Bushmen enumerated in the 1912 Grootfontein census, some 997 were already listed as working for settlers. Trooper Walbaum also observed that most of the farm laborers in the district were Bushmen.

As part of the effort to implement these laws, the territory underwent administrative re-organization and the formalization of the bureaucracy. The number of administrative districts increased from six in 1903 to sixteen in 1914 . The establishment of a police zone in the north and a Sperrgebiet ("prohibited area") in the Namib Desert served to concentrate the settler population in the center of the country. While the military was reduced in size from 3,988 in 1907/1908 to 1,970 in 1912, a police force was created in 1905 to fill the vacuum. In 1907 it consisted of eighty-four Europeans at thirty-two stations; ${ }^{32}$ by 1913 the police force consisted of at least twenty-eight sergeant majors, 532 Europeans, and 370 native police based at 111 stations. $^{33}$

Not only the significant expansion in European settlement after the official ending of the 1904-1907 war but also the location of these settlers is important. One of the magnet areas was the northeastern district of Grootfontein, where a higher rainfall and many springs made the area attractive to smallholders. The extension of the railway line to the nearby Tsumeb copper mine, with its ready market, further served to enhance the area's appeal for settlers and speculators. Of the various towns and districts in Namibia, Grootfontein displayed the most rapid growth 
between 1911 and 1913. More telling, though, was the expansion of European farms in the district, from twenty-five in 1904 to 173 in 1913, encompassing 777,077 ha. The number of settler-owned cattle in the district increased from 7,600 in 1908 to 13,611 in $1912 .{ }^{34}$ Outjo District, lying directly adjacent to Grootfontein experienced a similar expansion with some 431,125 ha occupied by farms. This area was not terra nullius but, rather, the traditional habitat of Bushmen. If police are stationed where the trouble is, then these two districts were clearly the epicenter. By 1907 Grootfontein already boasted the single largest contingent of police-some eighty-two personnel, including one warrant officer and nine sergeants. In 1912 that dubious honor fell to Outjo. $^{35}$

These developments were indicative of, and led to, violence. As Stals points out, by 1910 the only real security problems for settlers in the colony were the Bondelswarts, part of the legacy of the 1904-1907 war in the far south, and the Bushmen in the north and east. ${ }^{36}$ A few murders of Owambo and German settlers by Bushmen led to an outcry in the settler press. Headlines like "Bushman Pestilence," "Bushman Plague," and "Bushman Danger" were common coinage. Powerful forces, namely the Luderitzbucht Chamber of Mines and the various farmers' organizations, called on the government to act. Especially egregious to the mining industry was an attack on some sixty-nine returning Owambo contract workers, which they felt would disrupt the labor supply. Energetic disciplinary action was called for, thundered the SüdwestZeitung, claiming that it was outrageous that two Bushmen armed with bows and arrows could put to flight a group of thirty Owambo contract workers, with an obvious, if unstated, impact on labor recruitment. ${ }^{37}$ Reinforcements and "mobile" police stations were necessary.

Similarly, the Deutsche-Kolonialzeitung complained in of attacks on Owambo migrant-contract laborers and reported that the Grootfontein District Council had, by a large majority, voted to place non-working Bushmen on a reserve on the other side of the Police Zone, an area beyond that recently occupied by European settlers. ${ }^{38}$ Captured Bushmen were to be sent to work in the diamond mines in Ludertizbucht. These suggestions received a sympathetic hearing in the colonial press and among officials. $^{39}$

The supposedly liberal Governor Theodor Seitz, advised by Native Commissioner Kurt Streitwolf, also a "liberal," ${ }^{40}$ opted for a strong-arm strategy, increasing the number and power of police and military units in the troubled area and proclaiming, inter alia,

1. When patrol officers of the police are searching Bushmen areas, breaking up their settlements or searching for cattle thieves and robber bands, they must have their weapons ready to fire at all times, using of course the utmost caution.

2. Firearms are to be used in the slightest case of insubordination against officials. When a felon is either caught in the act, or when being hunted down, "does not stop on command" but tries to escape through flight.

3. The native police servant who is accompanying or guiding a patrol may carry a firearm, model 71 (Mauser rifle) with full responsibility in all areas where the Bushmen live.

The way in which State officials are to act towards Bushmen is regulated by the following rules. Even though it may be difficult, one should strive to keep the Bushmen at work. Forced dislocation of a Bushman werft [encampment] may only take place if they have been stealing stock or robbing or have attacked Europeans or their native workers ... 
If some of the male Bushmen who have been arrested are strong enough to work, they should be handed over to the district authorities at Luderitzbucht to work in the Diamond Fields. ${ }^{41}$

Seitz's immediate subordinates felt that these draconian measures did not go far enough. More specifically, the commander of the Schutztruppe felt that the Verordnung was unsatisfactory because the term "felon" would raise problems; he urged that the proclamation be amended to state that any Bushman who did not stop on command could be shot. Since it was impossible to say from which werft (loosely, "encampment"_) the alleged culprit came, he said, "it was nearly futile not to break up and arrest the members of all the settlements in the area where the patrol is operating." The district commandant of Outjo went even further: he wanted to include women in the definition of Bushmen, as they "were just as dangerous." Only one district commandant, Beringar van Zastrow of Grootfontein, felt that Seitz's measures were too draconian, but even his protests were muted.

Given the broad interpretation of what constituted the "slightest case of insubordination," or even the Germans' dubious linguistic capacity to tell Bushmen to stop "on command" and the fact that it was common knowledge that Bushmen fled at the sight of any patrol, this Verordnung constituted, in effect, as later events were to show, a warrant for genocide. Insofar as it was crucial in providing a legal underpinning for sustained purposeful action by officials and settlers to carry out a policy referred to in the settler press and administration as "Ausrottung" (extermination), this was more than simply an episodic massacre or pogrom; it was embedded within settler society. Of course, the creation of the United Nations Convention on the Prevention and Punishment of the Crime of Genocide was still several decades away at the time of these events, but, like genocide scholar Helen Fein, I treat this as a sociological genocide. All the facilitative characteristics for genocide were presentdeep structural divisions, identifiable victim groups, legitimating hate ideology and a breakdown of moral restraints, and what we might call "audience obliviousness" (toleration by local, national, and international communities). ${ }^{42}$

Action was indeed thorough. The governor's annual report for 1911-1912 notes that in that year alone police, often supported by soldiers, undertook more than 400 Bushman patrols in the Grootfontein, Outjo, Rehoboth, and Maltahohe districts, covering some $60,000 \mathrm{~km}^{2}$. Attempts at controlling vagrants, mostly Bushmen, by issuing metal "dog tag" passes were so unsuccessful that settlers, the press, and the Landesrat discussed the possibility of tattooing Bushman vagrants, but this suggestion was dropped, largely because of "technical difficulties" and the possibility of public outcry in Germany. ${ }^{43}$

Still, the "Bushman problem" did not go away. In April 1912, Seitz addressed the Landesrat, acknowledging that there were still many difficulties because of robberies committed by Bushmen in the Grootfontein, Outjo, and Maltahohe Districts and that there was a need to further increase punishment. ${ }^{44}$ By early 1912, the area west of the Etosha Pan had been "cleansed" of Bushmen and the police station at Okakeujo reinforced with additional personnel. Attacks on Owambo migrant workers, however, continued to such an extent that the Luderitzbucht Chamber of Mines urgently requested the government to "please be so kind as to immediately start with the sanitization of the Bushman hordes in that area." 45 The Chamber of Mines was supported by the Outjo district head, Dr. Schultze-Jena, who proposed that all Bushmen in his district be forcibly removed to the coast. The governor vetoed this suggestion, both because of the cost, which was estimated at 
between 50,000 and 60,000 marks per annum, and out of concern that such a strategy might draw unwelcome public criticism in Germany; more specifically, there would be a "very undesirable public discussion if natives who have not broken the law were to be removed as prisoners to an area where the climate would kill many of them." 46 The troops sent to deal with these raids found it almost impossible to control the Bushmen, who could easily escape into the thick bush with its many hidden springs. The only workable solution, the governor believed, was to provide military escorts to Owambo workers. ${ }^{47}$

A short while later, the acting head of Grootfontein District, Otto Link, urgently requested that the governor deport all the collected Bushmen to the Luderitzbucht diamond fields. Moreover, he urged, the military should assist, as the police were too few to undertake preventive patrols. Now was the time for raids against the Bushmen, he felt, as they were congregated around waterholes for the winter prior to the rains. A negative response from Windhoek did not stop Link from proposing the same total deportation or "cleansing" policy for his district the very next year, in response to a unanimous petition from the local Farmers Union, which begged the Kaiser to undertake the "most stringent possible measures to end the present situation" because life and possessions of farmers were in "high danger" from "every Bushman from the Otjijita Mountains to Nurugas who are nomadic." ${ }^{8}$ This time the governor, angered by the murder of two white settlers by Bushmen, agreed, and thirty additional troops were seconded to deal specifically with the "Bushman danger." A short while later, Link reported that the Army's 4th Company had managed to kill ten Bushmen and capture thirty. ${ }^{49}$

Official documentation is suggestive about the atmosphere reigning in Grootfontein settler circles. In a sworn deposition in a court case tried by the South Africans, one Farmer Thomas averred,

In 1911 I had a fight with Bushmen. I shot one and wounded, I believe, three or four. I was never tried by a German court for having shot these Bushmen. I have accompanied the German police and troops when they used to hunt Bushmen but I do not know how many Bushmen I shot then. ${ }^{50}$

In early 1915, Farmer K. Boehme of Kakuse West wrote to Governor Seitz concerning the problem of labor and the "more burning question" of how to protect settlers from Bushmen. Although he had given his Bushman laborers meat, they had run away and then attempted to drive off livestock, but he and some Herero tracked them for about $7 \mathrm{~km}$ :

There we found a fire with five Bushmen sitting around it. Unfortunately, they ran away too soon because of my dogs. But one was grabbed by my dogs and prevented from fleeing. He then grabbed for his bow and arrows but was stopped by my twelve-year-old Herero helper who called for help whereupon I fired. I recognized the corpse to my astonishment as [illegible] the Bushman [illegible] who had been taken to Tsumeb about three weeks ago. My two Herero assistants claimed to recognize all five Bushmen [illegible].... (Included a ca. seven-year-old) ... I have repeatedly requested the competent District Office to deport the Bushmen or to kill them off [abschiessen]. It seems that I will only get an answer to the Bushman question if I write directly to the Imperial Government or to the Colonial Office. ${ }^{51}$

Boehme was friendly with another farmer, Karl Wilhelm Becker, who in 1916 was charged with murder, having killed two male and four female Bushmen (two of them children) when he surprised them eating his ox. He was accompanied by a farm laborer, a Bushman named Max, who said he had "not reported the matter to the police 
because I was afraid the Boss would have killed me if I did so. I ran away when we got to the house. I ran to the Sandveld because if I went towards the Police Station the master might have found me on the road and shot me." Becker openly boasted about his Bushman-hunting exploits to the police. The South Africans found him guilty of murder and sentenced him to life imprisonment, citing as mitigating circumstances the fact that the German administration had condoned such killings. ${ }^{52}$

Captured Bushmen were usually deported to the coast to work in cold and damp conditions at Swakopmund and Luderitzbucht, and sometimes in the mines at Tsumeb. ${ }^{53}$ Hard statistics are difficult to come by, but some indicators are available. A letter from the Grootfontein District secretary reports twenty-seven Bushman men, twenty-four women, and twenty-four children captured. Of these, twelve men, two children, and two women were being sent to Swakopmund. The women were wives of men killed in skirmishes with troops, and it was assumed that they would hate settlers and perpetuate acts of brigandage. One survey of Bushman prisoners in Swakopmund lists thirty-two, of whom fifteen died within a year. ${ }^{54}$

\section{Booty Capitalism}

Karl Marx, of course, called this process of accumulation by dispossession "primitive accumulation." Noting the contemporary ubiquity of "primitive accumulation," , David Harvey prefers the term "accumulation by dispossession." 55 Max Weber was also concerned with social processes of this nature, which he termed "booty capitalism" or "adventure capitalism," a rather daring and ruthless predatory form of capitalism in which profit is made possible by direct force or domination. It was, said Weber, a largely unethical capitalism, inspired by the "inner attitude of the adventurer, which laughs at all ethical limitations.... Absolute and conscious ruthlessness in acquisition has often stood in the closest connection with the strictest conformity to tradition."56

A characteristic emphasized by neither Marx nor Weber-nor, indeed, most works on colonial genocide-concerns demographics. ${ }^{57}$ In such booty-capitalist or "primitive accumulative" moments, there is typically a severe gender imbalance. Men overwhelmingly predominate. Leaving aside the sizeable male military presence in German South West Africa in 1912, there were 9,046 adult male Europeans over fifteen, of whom only 2,438 were married. Of those claiming to be married, 1,970 had European wives living with them, 421 claimed absentee European wives, and fortyseven were married to "coloreds." ${ }^{5}$ Immediately before World War I, settler gender balance reached its most equitable, with one woman for every five men. ${ }^{59}$

During this period, there were five factors relevant to a proclivity to violence, factors that, in certain combinations, can produce a lethal cocktail for potential violence, including genocidal violence. First, and most importantly, as David Courtwright has shown, wherever there are large concentrations of single men, violence in its various manifestations is endemic. ${ }^{60}$ Colonial writers often took a certain pride in the violent colonial ethos. ${ }^{61}$ Violence was both action and attitude. After a visit to Luderitzbucht, prospector Fred Cornell described the treatment of Herero and Nama prisoners:

I had seen something of this myself, and had heard more from ex-German soldiers themselves, who with extraordinary callousness used to show whole series of illustrated postcards, depicting wholesale executions and similar gruesome doings to death of these poor natives. One of these, that enjoyed great vogue at the time, showed a line of ten Hottentots dangling from a single gallows. And each and every German soldier in the photo was striking an attitude and smirking towards the camera in pleasurable 
anticipation of the fine figure he would cut when the photo was published. This, I repeat, was only one of many that enjoyed a big sale in German South-West for the delectation of admiring friends in the Father-land. Absolutely no mercy was shown to these unfortunate creatures ... ${ }^{62}$

Such everyday visual acceptance-and, indeed, active encouragement-to treat the other as decidedly inferior was an important factor in creating and sustaining the local Zeitgeist in which genocide could occur.

The second factor relates to sex. Some contemporary accounts estimate that $90 \%$ of all white men lived in so-called concubinage relationships; while such relationships might have dampened disorder and violence, it was government policy to actively discourage them, especially after $1904 .^{63}$ At the same time, such relationships precipitated violence. The first South African military magistrate in the Grootfontein District admitted, "It seems that the Bushmen have lost all faith in the white man's methods [of justice], more especially as their women were being constantly interfered with by both farmers and police."64 Major T.L. O'Reilly, the military magistrate who drafted the Blue Book on Germany's treatment of the natives, concluded that, based on evidence from missionaries and German officials and statements by natives, "The chief cause of all the trouble between Germans and Bushmen was that the Germans would persist in taking the Bushwomen from their husbands and using them as concubines." ${ }^{65} \mathrm{He}$ also cited Johannes Kruger, described as "an intelligent Cape Bastard," who in 1895 was appointed by Governor Leutwein as "Chief of the natives of Grootfontein," as claiming that "the whole district is full of these German-Bushwomen cross-breeds."66 This, in turn, generated fears of Bushman "Retribution," which settlers believed was best pre-empted by killing.

A third factor relating to the demographic imbalance concerns alcohol, the misuse of which is generally a valid indicator of social disorder. Alcohol consumption among settlers was striking. In 1903, of the 167 firms and companies licensed in the Schutzgebiet, one-third were involved with the alcohol trade. By 1913, there was one commercial drinking establishment for every seventy-eight Europeans; Windhoek, with a population of 500 Europeans, had fourteen public bars-approximately one bar for every forty-one settlers. ${ }^{67}$ Tellingly, there was some criticism of settlers' excessive alcohol consumption, especially from the so-called moral purity movements in Germany. ${ }^{68}$ A Dr. Warneck, for example, complained that beer consumption in the Schutzgebiet was 50\% higher than in Germany. ${ }^{69}$ Others noted complaints that farmers would consume champagne for any slight occasion, despite having to pay twenty marks for a bottle; they drank it like soda water and called it "Farmer Weisse."70 Discussing unsuccessful horticultural smallholders, Clara Brockmann suggested that many failed not only because of "inactivity" and "stubbornness" but also as a result of "playing the great gentleman" and "drinking themselves to ruin by buying rounds of champagne." 71 Alcohol numbs the sense of bourgeois decency; the breakdown of "moral restraints" in facilitating mass killing is well known, and excessive alcohol consumption is generally associated with such breakdowns. ${ }^{72}$

Fourth, the socioeconomic background of all these rather virile male settlers needs to be considered. This is important, given Weber's insight about the connection between adventure capitalism and its "closest connection with the strictest conformity to tradition." Recalling his visit to the Schutzgebiet, Moritz Bonn observed,

In South-West Africa, we have created a kind of manorial system with a European lord of the manor and an African serf.... You quickly drift into European problems ... 
but whatever you do on African soil will always be merely "semi-European." The democracies you create are not a people, but merely a class, whose progress, existence and safety depends on the services of a subject race which they cannot amalgamate, but which they must rule. There lies ... the labour foundation of the African society. ${ }^{73}$

Most of the junior officials Bonn encountered

were scions of the Prussian nobility who had not learned much and who were suspicious of every kind of learning. They had come out to Africa because it offered them a chance of bossing on a scale no longer available even in darkest Pomerania. ${ }^{74}$

The Schutztruppe contained a high proportion of officers descended from distinguished military families, ${ }^{75}$ and their legacy lives on in the form of the fake Rhenish castles and massive monuments that are so popular with tourists nowadays. Even the missionaries Bonn found disappointing: "Their small-town minds had been trained in that docile obedience which was a distinctive feature of German Lutheranism; they did not dare to stand up for the rights of the natives or even for their own work."76 This mindset of arrogance combined with unquestioning acceptance of orders, or of the dictates of science, helped facilitate the exercise of killing people defined as "lesser," whether for the purposes of massacre or of genocide.

The fifth consequence of the demographics of settler society, as Courtwright suggests, concerns the important role of widespread rumors. ${ }^{77}$ Rumors were especially apt to generate insecurity when the settlers were thinly scattered on the ground. Paranoia was widely recognized. As Walbaum's commander advised, "The people out there will have some gruesome stories to tell you, but only half of them are true."78 Undoubtedly the situation bred a remarkable paranoia. Indeed, Jan-Bart Gewald sees paranoia as a major factor leading to the German-Herero War, and Isobel Hull reports that even General von Trotha suffered from fantasies in which he doubted the magnitude of the dying and believed that the Herero had simply vanished and would return to fight. ${ }^{79}$ Paranoia manifests and infiltrates the business of living in various subtle ways. While the laws were draconian, their effectiveness was constantly doubted, and attempts to ensure more regularization through the plethora of rules and regulations controlling indigenes served only to exacerbate the situation. ${ }^{80}$ The administration soon realized this:

[I]t will frequently be found that natives who are actually vagrants are in possession of registration badges, these are obtained from other natives or stolen. Care should therefore be taken that proper proof of employment is produced and that the native is in possession of his own registration badge. ${ }^{81}$

The colonial wars in Namibia between 1903 and 1907 were subject to extensive media scrutiny, ${ }^{82}$ at least in the early stages, or until the conflict began to drag out into a long and costly low-intensity guerrilla war, largely in the south and in the northeast. Abuses by settlers and officials led to sufficient public outcry that the Social Democrats and the various Catholic parties in the Reichstag were able to impose some controls on colonial affairs. Colonizers became acutely conscious that their actions were subject to careful scrutiny and criticism in the metropole. Comments like those made in 1906 by one Dr. Schaedler in the Reichstag obviously had an impact on settlers:

The story of our colonies contains a whole series of events of a not too pleasant kind; embezzlements, falsifying of evidence, senseless cruelties, assaults on women, horrible ill-treatment-things that do not contribute to a laurel wreath. The colonies must be no dumping ground for second-rate people. ${ }^{83}$ 
Fear of criticism influenced how they treated strangers who might be critical. Bonn, for example, found that on his 1907 visit, officials and many settlers refused to assist him in his inquiries until he threatened to make their lack of cooperation a matter of public record. ${ }^{84}$ Settlers and officials had reason to be suspicious of meddling metropolitan types because of the claims made in the Reichstag by one of its leading members, August Bebel, in 1905 to the effect that it was difficult for people to send unpopular reports to Europe and Germany about the administration there because if it became known who the individual was, "his entire existence is placed in jeopardy." 85 Similarly, for economic reasons, colonial civil servants, unlike their metropolitan counterparts, lacked tenure and thus were discouraged from questioning or taking a stand against abuses, and from criticizing their superiors, by the fear of losing their jobs. ${ }^{86}$

\section{The Musterstaat as Ceremonial State}

The situation in German South-West Africa was rife with contradictions. Settlers hated the indigenes yet depended on them; they disliked the government but relied heavily on it. In such circumstances, there was a strong emphasis-indeed, some visitors felt, an overemphasis_on ritual and ceremonialism. On a 1913 visit, South African anthropologist A. Winifred Hoernle complained, "It is awkward having anything to do with the Germans because rank counts so much and one can't get to the individual direct." 87 Excessive formality can disguise many features, including ignorance. The Weltanschauung of such persona, I suggest, had two important consequences. First, it produced an excessive reliance on the letter of the law; second, it meant that the words of academics and scholars carried a certain, often exaggerated, authority. Both were crucial factors in the Bushman genocide.

Ritual plays a crucial role both in coping with uncertainty and insecurity at the individual level and in state formation at the collective level. The casual observer of colonial photographs ${ }^{88}$ is struck by the immense time, money, and effort spent on secular ritual. Many have argued that inculcating awe and respect for the colonizer was more important than force as a means of ruling, and here "invented traditions," such as commemorative events, frequently justified by monuments, were especially important. Certainly they were deployed for such purposes in Namibia, given the fractured and politically divisive nature of the Namibian settler community. While Helmust Bley is undoubtedly correct in noting their emotional and political impact upon indigenes, ${ }^{89}$ my concern here is to note their impact on the colonials as well.

Often ignored but crucial were the day-to-day rituals, and, indeed, this was where natives experienced the state. There was a veritable industry for socializing intending settlers, which covered the gamut from Handbucher für Auswanderungslustige (handbooks for those intending to travel abroad) to special schools in Germany, and "proper" interracial etiquette featured prominently. ${ }^{90}$ Laws underwrote seemingly trivial daily interaction rituals of subordination for indigenes, such as prohibiting indigenes from walking on sidewalks and forcing them to greet settlers respectfully and not to make loud noises. Laws also reinforced certain stereotypes. Consider the väterliches Züchtigungsrecht, the law of paternal chastisement. This meshed well with the notion that indigenes were like dependent children who had to be disciplined in order to become well brought up, a notion lent added credence by the fact that in Germany corporal punishment was allowed only in schools and in the home.

Given the shortage of personnel to enforce compliance, interaction rituals between colonizer and colonized took on an added dimension. The colonial situation calls forth 
exaggerated etiquette from both colonizer and colonized. According to Albert Memmi, "formalism is the cyst into which colonial society shuts itself and hardens, degrading its own life in order to save it. It is a spontaneous action of self-defense, a means of safeguarding the collective consciousness." 11 Memmi has noted the profound ambivalence that permeates the colonial project: How could the colonizer look after his workers while periodically gunning down a crowd of the colonized? For the colonizer, to think about the contradictions inherent in colonialism was to undermine it. The panoply of legislation and the activities of scholars represented a mechanism for the colonizers to grant themselves self-absolution.

This image of a smoothly functioning social order creates the capacity for fascist self-delusion. As Erving Goffman has noted:

A performer may be taken in by his own act, convinced at the moment that the impression of reality which he fosters is the one and only reality. In such cases the performer comes to be his own audience; he comes to be performer and observer of the same show. Presumably he intracepts or incorporates the standards he attempts to maintain in the presence of others so that his conscience requires him to act in a socially proper way. It will have been necessary for the individual in his performing capacity to conceal from himself in his audience capacity the discreditable facts he has had to learn about the performance; in everyday terms, there will be things he knows, or has known, that he will not be able to tell himself. ${ }^{92}$

\section{Recht Machen mit Rechtsstaat (Making Right with a Rechtsstaat)}

Settlement involves not only physical movement but also a psychic domain: angst and other anxieties must be allayed for settlers to be settled. Law is crucial in this operation, creating what Jürgen Habermas has termed "facticity."93 Settlers, while in a position of domination, suffer the unbearable powerlessness of "waiting"94 and seek to stabilize their situation through the magical use of law. As an ideology, law contributes to the social construction of the social world by creating images of social relationships as natural and fair to the settlers because they are endowed with legality.

The emphasis on the instrumentality of legislation has diverted attention from the contradictions inherent in it. We must look not only at what the law says but also at what it does. In particular, the cultural and attendant "moral" meanings of this legislation have been ignored. The 1907 Native Regulations were important for the settlers not only on an instrumental level but also on a symbolic level. For the first time, the distinction between "whites" and "indigenes" was legally recognized," and thus the issue of sovereignty was touched upon. Sovereignty is not about determining the law but about determining who is exempt from it, as Giorgio Agamben has argued. ${ }^{96}$ But there are two types of exemptions: first, those whereby those with power can ignore the law and foist their will upon the less powerful; and, second, those whereby the vulnerable and less powerful are defined as beyond the law, as Vogelfrei (literally, "free birds"). The latter is obvious, if frequently overlooked, in von Trotha's infamous "extermination order," the very first sentence of which is "you have ceased to be German subjects"- the implication being that, as non-German subjects, they are beyond the realm and protection of German law. This idea meshed well with the German jurisprudential notion of Rechtsstaat (roughly translated as "constitutional state"), which, essentially, makes everyone equal who is subjugated by the same law within the bounds of the state. According to the Native Regulations, indigenes without labor contracts were without legal rights and could be punished as vagrants. 
It also validated the ability of settlers to engage in private policing. The Musterstaat survived by franchising its legal use of violence to its settlers.

Authorization or legality displaced legitimacy as a key concern. In the Schutzgebiet, as in apartheid South Africa, oppression occurred not so much through terror per se as by the routinization of terror in day-to-day interaction. "Lumping it" (ignoring the state officials) or "redressive self-help" (do-it-yourself justice) were apparently common settler strategies on the outlying farms, especially in the Grootfontein and Outjo Districts. ${ }^{97}$ Indeed, these strategies led to a sub-genre of German colonial literature, epitomized most notably by Hans Grimm, author of the influential Nazi-era bestseller Volk ohne Raum ("A People without Space"). Such misguided settler self-help was not seen as mistreatment but justified as "discipline" (Züchtigung).

Another level at which the Rechtsstaat played a role was the quality of the formal judicial structure. Even while en route to Swakopmund from Germany, General von Trotha issued orders empowering every commanding officer to suspend preliminary judicial proceedings and to shoot any enemy. Other "colored" inhabitants, if suspected, were to be tried by field courts. ${ }^{98}$

In 1912 a Dr. Müller complained in the Reichstag,

Our civil and military administration of justice is simply indefensible.... With regard to native justice and administration there exists an incredible uncertainty concerning the powers of the administrative authorities.... One judge uses the German penal code without further ado.... Another does not use the penal code at all. In short, our criminal proceedings leave the natives entirely without rights. ${ }^{99}$

The courts were lenient when forced to take action against settlers for killing indigenes; homicides were invariably justified as "accidental" or as necessary for "public safety." 100 Settlers frequently justified their own actions and mistreatment of indigenes by referring to the actions of von Trotha and other (quasi-)legal officials. In Namibia, Harry Schwirck concludes, "a whole legal discourse and law itself enabled rather than restrained colonial abuse."101

\section{Bleibt da etwas anderes ubrig als Erschiessen? Soft alternatives to genocide?}

The infamous 1911 Verordnungen were not the result of a unanimous decision. Rather, policy makers had to accommodate different stakeholders, and the results must be seen as part of a larger policy debate about the "Bushman Danger," which drew upon historical and "scientific precedent" and which produced three options in addition to direct extermination. The first of these involved "cleansing" the area by deporting captured Bushmen to the coast or driving them into the vast sandy waterless area to the northeast of Grootfontein, known as the Kaukauveldt (an area deemed unsuitable for European settlement). This was the option favored by many settlers. A second option was to "civilize" Bushmen by habituating them to work. This option was given lip service by occasional settlers but did not form part of settler ideology; on the contrary, settlesr were very suspicious of attempts to link education with labor laws. ${ }^{102}$ The main proponents of this option appear to have been missionaries and some humanitarian-oriented officials. The third option was the creation of special "reserves"-what were known in Europe as "ghettoes"-for Bushmen. In a sense, this was a compromise favored by officials as a way to circumvent criticism from the metropole, even though most believed it to be unworkable, given the Bushmen's alleged inherent Wanderlust. 
The reserve option was given official credence in a memorandum drafted by Dr. Seibert, the government's chief medical officer:

[Bushmen] are unsuitable as settled employees, and the relinquishment of their nomadic lifestyle spells their doom. While they are of little economic value, they are of large scientific value. And even the Cameroons have a law, which protects gorillas by placing them in reserves. ${ }^{103}$

Copies of Seibert's letter were sent to all the relevant district heads for comment; all the comments were negative, with the notable exception of those of Beringar von Zastrow, the Grootfontein Bezirkamtmann (district head), in this case supported by the farmer-dominated Grootfontein District Council, which had requested that all "non-working" (?!) Bushmen be placed on a reserve. Von Zastrow felt that the area northeast of Grootfonetin, beyond the police zone (an area settlers could only enter with special permits), already constituted a de facto reserve. Objections raised by the other Bezirkamtmänner included the following: that reservations would lead to a concentration of stock thieves and vagabonds; that it was impossible to keep the Bushmen within a demarcated area; that the landscape would be damanged through their hunting methods and veldt-fires; and that this policy would hinder efforts to educate "Bushmen through labor." The Maltahöhe Bezirkamtmann characteristically replied that it was debatable whether there were any full-blooded Bushmen left, and a reserve would simply be a hiding place for runaway servants. Bushmen had excellent potential to serve as herd-boys. He concluded that

[a] wild animal (or gorilla) can be held captive for breeding in which case the race would not become extinct by the process of natural selection. It is not possible to hold a Namib Bushman captive because they are still human beings, but they have no pride in their race, in fact they are without racial consciousness. ${ }^{104}$

His Outjo colleague argued that the scientific value of the Bushmen was minor compared to the security threat they posed to Owambo contract workers and white settlers.

The notion of a reserve was first mooted in 1906, when the prominent Berlin ethnologist Felix von Luschan suggested the creation of a South African Bushman reserve in the "interest of science." 105 The Deutsche Kolonialzeitung took up the theme, arguing that the suggestion was also applicable to Namibia. ${ }^{106}$ The Kalahari was the last asylum of the "vertreibenen Ureinwohner [expelled Aboriginals]." The following year, Lt. P. Gentz, an officer with many years' field experience, made a strong plea:

With the death-knell of these people ringing, one wishes that there was a reserve for them, as there are for the lazy Herero and Hottentots. A reserve where they can live in peace and where they can maintain their lifestyle so important for scholarly research. ${ }^{107}$

Most officials with experience in Grootfontein, including von Zastrow and Hauptmann Müller, felt that a Bushman reserve already existed, created by the Bushmen themselves, in the Kaukauveld, but that forcibly moving Bushmen there was problematic not for ethical or ethnographic reasons, such as infringing on the territory of others, but_as Müller put it in 1912-because "I have never heard of anyone being successful at driving jackals before dogs." 108

At present, data are scanty, but it is surely more than coincidental that, at the time when missionary Heinrich Vedder of the Rhenish Missionary Society and von Zastrow the Grootfontein Bezirkamtmann were expressing concern about the wholesale decimation of Bushmen, Reinhard Mumm, a leader of the Moral Purity Movement 
and recently elected member of the Reichstag, made an eloquent plea for a reserve for the "poorest of the poor ... the slaves of the slaves." Bushmen, he claimed, were a product of a tragic history, dispossessed by farmers and railroad companies and riddled with venereal disease. As a reserve, Mumm suggested the area stretching from the Grootfontein farms to the Kavango River. He repeated his call for a Bushman reserve in $1914 .{ }^{109}$ While Mumm's plea did not have much impact, it is clear that there was an important information network linking the colony to the metropole.

The issue of whether Bushmen could be "habituated" to work also provoked much discussion among academics. The academic who provided the immediate reference point for the debate was the geographer Siegfried Passarge who, in 1907, published a compilation of his contributions to the Mitteilungen aus des deutsches Schutzgebiets as a book. His research was based on a sojourn of a few months in the Kalahari on an expedition led by Lord Lugard and accompanied by a Dutch-speaking Bushman. Most of his information was derived from white traders or Bechuanas, since he found it difficult to get information directly from Bushmen: "Nothing is more changeable, undependable, and unpredictable than the character of the Bushman; it combines within itself the greatest imaginable contrasts, virtues, and vices."110 As a race, Bushmen were on a closed development path, he claimed; they were incapable of adapting to agriculture or pastoralism. Passarge concluded that the only viable policy, in a settlement situation, was extermination:

What can the civilized human manage to do with people who stand at the level of that sheep stealer? Jail and the correctional house would be a reward, and besides do not even exist in that country. Does any possibility exist other than shooting them ${ }^{111}$

Passarge's efforts were sufficient to get him appointed, in 1908, to the inaugural Chair of Geography at the Hamburger Kolonial-Institut, the only geography department devoted solely to colonial geography.

Franz Seiner, an Austrian geographer, also participated in this discussion. He argued that adult male Bushmen were incorrigible, and thus best deported from the area where captured. The way to make Bushmen into reliable laborers was to start with the children and re-socialize them from an early age, divorced from their traditional milieu and from their parents. Bushmen were in no danger of extermination by farmers, he argued, because they had a vast "natural reserve" in the Kalahari. At the same time, Seiner felt that if women were placed on settler farms they would begin miscegenating with local blacks, leading to an overall superior labor force. He suggested that all the northern Bushmen-that is, those north of Grootfontein-were "Bastard Bushmen" (hybrids), and thus not an Urrace worthy of protection. ${ }^{112}$

In reality, as Lydia Höpker's memoir attests, all these options were being practiced simulanteously. Bushmen were hunted, shot, and driven out of their areas, and their children were press-ganged into serving as cheap labor for farmers. Many officials used the belief that the Bushmen were already a "Bastard race" to argue against any need to "preserve" them.

Seiner's and Passarge's were not isolated academic voices. On the contrary, we should consider, for example, the remarks made by Leonard Schultze, a renowned geographer-anthropologist with extensive field experience in both Namibia and New Guinea. Schultze's study of the Nama ${ }^{113}$ is widely regarded as definitive, and he coined the term "Khoisan," which lumps "Bushmen" and "Khoi"(or Nama) together. Schultze undertook his research in Namibia during the notorious wars of 1904-1907. He profusely acknowledged the assistance given by General von Trotha, lauded as a fellow Naturforscher (natural scientist). Indeed, Schultze accompanied the German 
troops in their last great flanking movement, which led to the death of Nama leader Hendrik Witbooi, and then accompanied Hauptmann Ludwig von Estorff in his famous tracking expedition, which pursued fleeing Nama and their allies to Rietfontein in the southern Kalahari. Obviously the war situation restricted his travels, and his research was carried out only in a small part of southern Namibia. The sample on which his famous classification is based was neither random nor large; it consisted of measuring twenty-six people in Walvis Bay and the rest, some fifty prisoners, almost exclusively in Keetmanshoop. Schultze measured some ninety characteristics, including such arcana as breast circumference, while the genitalia of his twelve female subjects enjoyed special emphasis. Six people measured in southern Botswana (Lehututu or Letlake Pan), together with three Namib Bushmen, constituted the "Bushman" sample. Given what we know about naming practices and theories of the time, it seems likely that his "Bushmen" were impoverished "Nama," and thus his new term simply reinforced conventional dogma. ${ }^{114}$ There was economic value in such "lumping." A few years after undertaking fieldwork that led to this formulation, he inveighed as follows:

The ethnologist may lament the fact that a portion of humanity with such strongly developed characteristics as displayed by the tribes of German South West Africa ... will one day become wholly melted down in order to be put into circulation again as common day labor coin, stamped with the imperial eagle and the Christian cross, with the inscription "colored laborer," to constitute an economic value. But the struggle for our own existence allows no other solution. At the same time, work is the only solution for them: he who doesn't want to work perishes here with us as well; we have no reason to be more sentimental in Africa than in Europe. We who build our houses on the graves of those races must, however, take twice as seriously our obligation to avoid no sacrifices for the purposes of civilization, that is, for the greater development of all means of existence in this new land. ${ }^{115}$

Given such a Weltanschauung, Schultze's views on Bushmen are not surprising. He considered them the lowest of the low:

If we consider the natives according to their value as cultural factors in the protectorate, then one race is immediately eliminated: the Bushmen. The Bushman lacks entirely the precondition of any cultural development: the drive to create something beyond everyday needs, to secure or permanently to improve systematically the conditions of existence, even the most primitive ones like the procurement of food. In the course of centuries he has come into contact with cultures of all levels; in conflict with them he has often enough had the knife put to his throat; tireless missionaries have attempted to save him from such struggle, to protect and to join him as the modest member to a civilized community; but the Bushman has always run away. He feels better out in the Sandveld behind a windscreen of thin-leaf thornbush than in a solidly built house with a full pot and regular work-as long as he is free. Colonists cannot count on such people; they let them live as long as at least they do no damage. But when they do not fulfill this requirement, they have been killed off like predatory game. The idea has been considered to preserve the Bushmen in reservations as the last remnants of the primordial past of the human race, just as elsewhere attempts are made to save endangered animal species. But we will not be able to afford the luxury of leaving fallow the required land areas and everything else which man requires for the maintenance of the species without inbreeding. ${ }^{116}$

Even scholars defined as "liberal' supported this view. Paul Rohrbach, for example, suggested that "in Africa the extermination or the decay of the natives is impossible, excepting perhaps the few Bushmen in the southwest who at present are giving us serious trouble." 117 To be sure, there was some criticism of this position from the 
slightly more liberal anthropologists centered around the Zeitschrift für Ethnologie in Berlin, who in 1914 published von Zastrow's 1912 memorandum dismissing proposals calling for "shooting or deporting whole tribes as so absurd as not to deserve any consideration"118 and opted instead for economic integration and education. But this was decidedly a minority view. More typical was George McCall Theal, the leading South African historian, who carefully studied the available evidence and concluded in 1919 ,

It can now be asserted in positive language that the Bushmen were incapable of adopting European civilization.... To this day there has not been a single instance of a Bushman of pure blood having permanently adopted the habits of the white man. ${ }^{119}$

The relative importance of science and the practice of science in Germany vis-à-vis other colonial powers should be noted. German anthropology dominated its English and French counterparts; as early as 1885, von Luschan could already boast that the "Berlin collection is seven times as big as the ethnographic department of the British Museum." As late as 1920, with Germany stripped of its colonial possessions, the Berlin Gesellschaft für Anthropologie, Ethnologie und Urgeschichte had more members than the Royal Anthropological Institute and the American Anthropological Association combined. Even smaller German societies outdrew their British and US counterparts. In 1906, the Vienna Anthropological Society, for example, could claim 459 members. ${ }^{120}$ Given the mandarinate nature of German academe, this meant in practice that academic and scientific pronouncements enjoyed a much wider currency and authority in Germany than in the other metropolitan centers. Even critics of colonialism, such as Moritz Bonn, conceded that German scientific colonialism was more advanced than the British or French versions. It is within this context that one can appreciate von Luschan's claim that he was "entirely convinced that our late war in South-West Africa might have been avoided, and that it was simply the result of neglect of the teachings of ethnology on the part of leading officials." 121

Certainly officials took scholars seriously. In November 1912, Franz Seiner wrote a letter concerning Bushman prisoners to the colonial secretary and enclosed photographs to illustrate his point about their mistreatment. His letter was forwarded to Governor Seitz for comment. Ten months later, after investigating the matter, the governor replied that he had no doubt that, if published, Seiner's photographs would provide "unpleasant agitation material against the Territorial administration." He then added, in a trope familiar to science, that

a more objective view of the situation must take into account the fact that the Bushmen are by no means only harmless children of nature, but constitute a serious danger to more intensive settlement of the fertile northern districts. Weakness cannot therefore be justified by any means in the treatment of the Bushmen. ${ }^{122}$

These photographs are important-indeed, damning-for what is not discussed in the resulting correspondence. Two of the prisoners have amputated arms; this was a common way of dealing with Bushman "theft," yet neither then nor later did such practices merit discussion, let alone criticism. ${ }^{123}$

While sweating at their uneconomical smallholdings in the Grootfontein district, many inexperienced and underfinanced settlers projected their wildest fantasies upon the "vagabond Bushmen," and their fantasies often meshed with those of academics. The same can be seen in the numerous reports written by officers and officials that were published in quasi-academic journals. With the exception of Seiner, the scholars whose material and ideas were so eagerly read and used by officials and settlers were 
not in Namibia during the period when these Bushmen "hunts" were carried out. They were still involved in Bushman issues, but they seem to have been exclusively concerned with Bushman penises! A major question troubling some of the finest scholars was how to distinguish between "Bushmen" and "Hottentots." Craniometrical differences between the two were insignificant, and thus the issue had to be resolved by other means. Within a few years the focus had shifted to penises as the differentiating trait. Especially influential were Seiner's research on and photographs of Bushman prisoners; Seiner argued that the semi-erect penis of the Bushman was a distinctive racial characteristic and that Bushmen could be identified by the angle of the penis: "Exceptionally interesting is the circumstance that Bushmen do not have pendular penises like the other human races, but are in non-aroused circumstances horizontal like four-footed mammals." 124

So intense was the debate over the Bushman/Hottentot distinction that Eugen Fischer, later to achieve a certain notoriety in Nazi Germany, wrote to Governor Seitz in 1913 requesting a Bushman penis. His letter contains detailed instructions about how to preserve the organ and the suggestion that if the governor had a condemned Bushman, the prisoner could be sent to Freiburg, where the cold climate would soon kill him and the good professor would have a fresh cadaver to work on. Bushmen's genitalia seem to have transfixed many physical anthropologists, and this fascination continued to be a popular trope in German physical anthropology. Fischer, too, associated the genitalia of Bushmen with attributed animality. Genitalia were seen as clinching their intercalary role between humans and animals-a belief that lasted into the 1950 s. $^{125}$

Seiner appears to have played a key role not only in stimulating this debate but also in directly and indirectly influencing official policy on Bushmen. Indeed, a closer reading of newspaper headlines featuring "The Bushman Danger" or "The Bushman Plague" indicates that all seem to be traceable to Seiner's pen. Some felt that his claims were exaggerated-so much so that Seiner tried to sue an experienced settler newspaper editor and member of the Landesrat, Rudolf Kindt, for libel after the latter accused him of presenting reports laced with fantasy. Kindt obtained sworn statements from Pater Bierfort, a Catholic missionary on the Kavango River, who pointed out Seiner's numerous elementary linguistic faux pas. Other expert witnesses testified to Seiner's "übernervoes" and overanxious state: he was prone to take exception to the smallest thing, and once punished his bambuse (factotum) with twenty-five lashes. Bierfort, who served as Seiner's interpreter, called his article on the "Bushman Danger" pure "invention." 126 Seiner left the country before the case was settled. The fact that other observers disputed his claims of danger raises an intriguing question: Were Seiner's (and, indeed, Passarge's) statements about Bushmen based on scientific observation, or were they generated from his interactions with settlers, and, having been given scholarly credibibility, did they then return to reinforce settlers' fantasies and nightmares? This interpretation seems not only possible but likely.

\section{Conclusion}

What was a small war for Germany was genocide for Bushmen. Émile Durkheim's distinction between necessary and sufficient conditions, first made in his classic study Suicide, is useful in examining this genocide. Sufficient conditions relate to intent (typically phrased in terms of policy), the focus of liberal analyses, while necessary conditions relate to structural features necessary for the genocide to occur. ${ }^{127}$ 
These conditions are not mutually exclusive but must be analyzed synthetically, since the problem in examining colonial genocide is not to explain it so much as to understand the variations that occur. As I have pointed out, structurally German South West Africa was a classic case of Marxian "primitive accumulation" or Weberian "booty capitalism." Seeing the situation as one of resource competition would appear attractive. Ecological pressure most certainly might have been a factor: as well as settlers' having moved into Bushman territory, 1910 had also been a bad drought year, with only $42 \%$ of the average annual rainfall. ${ }^{128}$ The fact that four of the following five rainy seasons also saw below-average rainfall aggravated the situation. In addition, the 1907 proclamation of the Etosha Game Park, in prime Bushman territory north of Grootfontein, and 1908 proclamations outlawing hunting out of season or without a written license conceivably added to the pressure. The Blue Book detailing Germany's treatment of the indigenes cites approvingly an earlier official report dealing with Bushmen in the northern Cape in which Major J. Herbst (secretary for South West Africa at the time of the Blue Book) states that "the strict enforcement of the game laws has made the country unsafe for them. They profess to be unable to understand by what right Government protects the game and invariably ask to be shown the government brand on the animals." 129

The problem with the ecological approach is that this was a case of genocide by long-term stealth. Bushmen, farmers, and officials occupied different ecological niches on the same terrain, and thus were not in direct or immediate competition. Rather, as in other parts of the Kalahari, a symbiosis emerged, and direct resource competition became an issue only much later. With respect to the game laws, it is obvious that state forces were thinly spread and had little chance of implementing these laws.

Theories on colonial genocides, those situations of brute "booty capitalism" or "primitive accumulation," often ignore the importance of demographics and of psychologically pacifying settlers. In Namibia the settlers were spread thinly and came from a strong German tradition. Had they been less "tradition-bound," they would probably have sought their fortunes in regions beyond German hegemony. In pacifying the colonizers, ceremonialism, and particularly the Rechtsstaat, played an important role. This emphasis fits the facts well and complements Isobel Hull's recent argument about the role of German military culture (understood as a complex of habitual practices and basic assumptions embedded in its doctrines and administration). ${ }^{130}$ In addition, German society valued the opinions of scholars to a far higher degree than other Europeans did. Indeed, the structure of both academia and the military had strong nationalistic overtones. This had important implications in facilitating the Bushman genocides.

Perhaps one of the most insightful analyses, not only linking Germany's colonial experiences with the rise of the Nazis but also delving into the nature of genocide, is that of Moritz Bonn, who, unlike Hannah Arendt and other intellectuals, actually had first-hand experience of the colonies. An unpublished, undated paper titled "End of the Colonial Discussion" (probably written in the 1930s, when Bonn was in exile) provides the following analysis:

[Nazis] accept and amplify the racial theories by which General von Trotha had justified his policy of extirpating the rebellious Hereros by making them die of thirst in the Omaheke desert:- that according to the law of nature inferior races must die out when brought in contact with superior races. The Nazi creed is based on the same cheap conception of Darwinism, and like their colonial predecessors, they do not believe in the unaided working of this supposed law of nature[.] 
The great Nordic race, as represented by Nazism, cannot defend itself against the Jews by its own superior values, except by closing all avenues of a living to them and by stealing their money. They are now doing on a much larger scale to the Jews what had been intended as punishment for the Hereros. The Hereros had undoubtedly rebelledthough they had been sorely tried-they murdered many German settlers; they had successfully outmaneuvered the rather theatrical German Army chief, who was ignorant of aboriginal warfare and in his wrath decided to inflict collective destruction on those who would not play the game of war in accordance with scientific rules. The Nazis hold German Jewry collectively responsible for the criminal act of a non-German Jew, who their own brutality had goaded into frenzied crime. His evil deed served them as a pretext, for a policy of expropriating, Jewish property ... the Commander in South West Africa had hidden himself behind the law of nature in order to justify his brutal reprisals; the Nazis are trying, as they have done all the time, to dress up their arbitrary, violent acts in the form of legality...

As long as they express such doctrines there should be no discussion of returning the colonies because to them justice is not an ethical conception, but a mere legal quibble. Germany must learn that recognition of the right of self-determination for a majority does not include the right of extermination of an alien minority. ${ }^{131}$

This unpublished document is cited for a number of reasons. To begin with, it establishes that Bonn rather than Arendt was the first to see the connection between the colonial experience and the rise of Nazi totalitarianism. ${ }^{132}$ There may be a connection between colonialism and totalitarianism, as Arendt suggested, but it is necessary to note that the critique of totalitarianism may also have some colonial roots, as in Bonn's case. Bonn's central insight, however, is to highlight the importance of the manipulation of legal ideology in setting the stage for genocide, directing attention to the importance of the Rechtsstaat.

In this case, the Rechtsstaat facilitated two outcomes. First, it franchised coercive power to settlers while at the same time empowering them psychologically. It had magical qualities. Rohrbach, formerly settlement commissioner for German South West Africa, complained, "The conviction has gained ground that without the formality of the law and the juristic atmosphere of our high Prussian-German officials, nobody can administer anything." 133 Nevertheless, such formality was a crucial factor in giving settlers a self-confidence that, Rohrbach believed, rendered them "spiritually more effective than any average million of people at home."134 Second, the Rechtsstaat attempted to create a supply of pliable labor by removing key elements of the means of production from a sizeable number of indigenes, especially Herero and Khoekhoegowab-speakers, by confiscating their lands and livestock and then attempting to tie them down to colonial employers through the permit system. Indigenes not on the reservations or carrying a pass were defined as criminal and punished as vagrants. Bushmen by definition, then, were vagrants and subject to punishment.

Justification for the Labor Regulations was couched in two ways: as a senior official told Colonial Secretary Dernberg during his visit to Windhoek, "If the natives ever become rich in cattle again, the safety of the country will be threatened." It was equally important that settlers, officials, and scholars shared a dominant view that the object of the laws was to create an indigenous proletarian working class. ${ }^{135}$ The official rhetoric of this milieu is rife with references to indigenes as "economic use units," as in Schultze's twisted phraseology, mentioned above, about the circulation of common labor coin stamped with the Imperial eagle and the Christian cross. Similarly, Rohrbach believed that indigenes had rights only if they could prove 
that they could work. ${ }^{136}$ In his popular Herero war novel, Peter Mohr's Fahrt nach Südwest Afrika, Gustav Frenssen has one of his soldiers exclaim, "These blacks deserved to be killed in the eyes of God and men; not because they murdered two hundred farmers and rose up against us in rebellion, but because they built no houses and dug no wells." ${ }^{137}$ The attributes of Bushmen epitomized the critical distinction between Herero and Bushman: in the hierarchical typology developed by academics, Bushmen ranked even below Herero and Nama because, it was alleged, they had no property. It is not enough to recognize this hierarchy as neo-Darwinian; crucially, we must consider the basis on which the hierarchy was constructed. According to many colonials, Bushmen were Vogelfrei, precisely because they owned no property or had laws. Their alleged incapacity to work was also tied to notions of property. Most importantly, having no property meant that their territory was seen as Herrenlos, or terra nullius, and thus available for the taking by settlers. ${ }^{138}$

For all the problems settlers claimed to have with them as workers, Herero and Nama could still be massaged into the system by manipulating their love of livestock. ${ }^{139}$ While indigenes were prohibited from owning livestock, farmers used this love as a means of ensuring labor. According to the Landesrat, indigenes owned about $25 \%$ of all small stock and more than 20,000 head of cattle. ${ }^{140}$ Most of this stock ownership was "informal," facilitated by settlers, since officially, between 1911 and 1914, the governor received only thirty-four applications for such licenses and approved thirty. ${ }^{141}$ Bushmen, believed to have no concept of property or wealth, could not be manipulated in this way, which gave emphasis to their "worthlessness" in settlers' eyes. As foragers, they were not dependent upon their colonial masters and could "drop out" or disengage from the colonial economy when they wanted to. This fact also facilitated the settlers' ability to project their worst fantasies and nightmares onto the Bushmen and explains why Bushmen served as convenient scapegoats to cover the incompetence of novice, and invariably underfunded, farmers. The Bushmen could not be controlled or integrated, and thus they had little "economic value."

While much effort has been expended in understanding that coterie of genocides known variously as "frontier" or "colonial" genocides, one of the major problems underlying these efforts is the issue of false comparisons. Invariably, the comparison is between Herero and Australian Aborigines. Alison Palmer, for example, distinguishes between "state" and "societal" genocides, the former referring to the Herero and the latter to Queensland, where genocide was not the product of direct state policy but, rather, the result of settler vigilantism tolerated by a state that lacked the resources to impose its will on the settlers. ${ }^{142}$ As the Bushman case shows, however, the boundaries between state and societal genocides are rather blurred. A comparison between the genocides of the Bushmen and of the Aborigines suggests several important similarities. Not only were both groups foragers living in mobile small groups with no clear-cut hierarchy, both had to deal with a sparse, mostly male, settler population. In terms of intellectual classifications concerning humans, it is no accident that, going back to the "Great Chain of Being," the two groups that were seen as most primitive were the Aborigines and the Bushmen. ${ }^{143}$

Perhaps the most important recent contribution to understanding colonial genocides has been that of Jürgen Zimmerer, ${ }^{144}$ who elaborates on Palmer's insights to make the case that such genocides occurred by way of pre-modern and incompletely bureaucratized states that could not control their unruly citizens (thus paving the way for vigilante action) and, at most, could only produce massacres, since they did not have the requisite organizational complexity. Zimmerer's analysis raises an important 
question: How does one understand the end of the Bushman genocide that occurred when the South Africans took over? Certainly the Afrikaner settlers who slowly but surely supplanted the German settlers were believed to be far more racist, even in German times, ${ }^{145}$ and the first South African administrators were notoriously unsympathetic toward Bushmen. Administrator A.J. Werth, for example, asserted that

We make no attempt to civilize the Bushmen. They are untameable.... The territory is so large and the Bushmen so cunning that an army might seek them in vain. But it is all fine country, splendid for sheep and cattle farming ... 146

In addition, the territory had undergone significant, if not massive, de-bureaucratization. In 1923, the administrator complained that the administration consisted of only 311 officials, of whom 212 were temporary employees, and that there were massive morale problems because of anomalies in pay and allowances. (In contrast, 1,226 German officials were deported.) Similarly, the police force decreased from 440 European and 330 native police to 284 European and 239 native police in 1923, while the number of police stations decreased from 113 to thirty-nine. ${ }^{147}$ Poor quality of personnel and woeful under-financing of transport was a constant administrative refrain-a situation conducive to vigilante-style actions against Bushmen, one would expect.

Bushman numbers belie the facile explanation that they had already been "tamed" by then. Nor is there any evidence that they were negatively affected by the great influenza epidemic of 1918. Three factors, I suggest, may be significant. The first relates to the notion of Rechtsstaat. For all the brute racism of the South African regime, there was no Rechtsstaat that could promote the grown of fascist self-delusion. Second, the South Africans deported most of the recent German settlers and left the alte Afrikaner who, like the racist but experienced Boers, realized that they had to live with the consequences of their actions and could not expect much state support. Finally, and perhaps most importantly, the South Africans did not want to be embarrassed at the League of Nations. They had painted the Germans as barbaric in making their claim for a Mandate, and thus could not afford to be accused in their turn of "barbaric atrocities." The so-called Bondelswarts Affair of 1922 had been a source of acute international mortification. The way in which the South African administration responded to even the most vague accusation that might reflect on their reputation as a competent Mandatory authority always seemed to involve a high-powered investigation and spin-doctoring. ${ }^{148}$ Public embarrassment by way of a free press, as a potential deterrent to atrocity, had already demonstrated its potential in Germany. Now it flowered. Clearly, the international politics of embarrassment as a means of genocide prevention can work in unanticipated ways.

\section{Notes}

1. National Archives of Namibia [NAN] A.214, "Kriegstagebuch von Gunther Walbaum, 1914-1915," 39 [Walbaum, "Kriegstagebuch"]. Unless otherwise indicated in the notes, all translations into English are my own.

2. Ibid., 42 .

3. Ibid., 49 .

4. NAN, ADM 13/35 Grootfontein, Lawlessness of Bushmen, 1915, Administrator to Military Magistrate (9 December 1915), 2.

5. NAN, ADM 13/26 Bushman raiders, Grootfontein, Magistrate Gage to Secretary of the Protectorate (21 December 1918). Like most German scholars, the Reverend W.A. Norton 
visited Bushmen in the Grootfontein prison: "The poor things were trembling visibly, and seemed to think I was come to execute them ... Some physical anthropologists, known to Cape Town, had recently visited them ... and hence perhaps inspired the terror which greeted me." W.A. Norton, "The South-West Protectorate and Its Native Population," South African Journal of Science 16 (1920): 453-65, 454.

6. E.g., Jacqueline Solway, ed., The Politics of Egalitarianism (New York: Berghahn Books, 2006).

7. See Robert J. Gordon, The Bushman Myth and the Making of a Namibian Underclass (Boulder, CO: Westview Press, 1992), which contains many of the empirical data on which this paper is based. See also Robert J. Gordon, "Covering the Tracks with Sand: P.J. Schoeman and Public Anthropology," Historia 52 (2007): 98-126.

8. Jürgen Zimmerer and Joachim Zeller, eds., Völkermord in Deutsch-Südwestafrika (Berlin: Ch. Links Verlag, 2003).

9. Ute Dieckmann, Hai//om in the Etosha Region (Basel: Basler Afrika Bibliographien, 2007); Gordon, The Bushman Myth, 218-19.

10. Kae Matundu-Tjiparuro, "Ovaherero Reparations Case Ongoing," New Era, 31 August 2005.

11. Jeremy Silvester and Jan-Bart Gewald, eds., Words Cannot Be Found: German Colonial Rule in Namibia. An Annotated Reprint of the 1918 Blue Book (Leiden: Brill, 2003), 235-45.

12. Lawrence Green, Where Men Still Dream (Cape Town: Howard Timmins, 1945); Lawrence Green, Strange Africa (1938; reprint, Cape Town: Howard Timmins, 1981); Lawrence Green, Lords of the Last Frontier (1953; reprint, Cape Town: Howard Timmins, 1981).

13. Sidney Legendre, Okavango: Desert River (New York: Messner, 1939); Negley Farson, Behind God's Back (New York: Harcourt Brace, 1941).

14. "Die verwaisten Kinder solcher Buschleute wurden an Farmersfrauen verteilt, damit sie diese aufzoegen und sie spaeter als Bambusen benützten." Lydia Höpker, Als Farmerin in Deutsch-Südwest (1936; reprint, Otavi: E. Will, 1997), 49.

15. Paul Vageler, Afrikanische Mosaik (Berlin: Paul Parey, 1941), 87.

16. e.g. Zimmerer and Zeller, Völkermord in Deutsch-Südwestafrika, 45.

17. David Pizzo, "Forged in Massacre: The Formation and Implications of European Conquest Tactics and Policy in the African Context" (MA thesis, University of North Carolina, Chapel Hill, 2001).

18. Zimmerer and Zeller, Völkermord in Deutsch-Südwestafrika; A. Dirk Moses, "Conceptual Blockages and Definitional Dilemmas in the 'Racial Century': Genocide of Indigenous Peoples and the Holocaust," Patterns of Prejudice 36, 4 (2002): 7-36.

19. Paul Rohrbach, German World Policies, trans. Edmund von Mach (New York: Macmillan, 1915); Moritz Bonn, Wandering Scholar (New York: Day \& Co., 1949).

20. Ernst L.P.Stals, Kurt Streitwolf: Sy werk in Suidwes-Afrika 1899-1914 (Johannesburg: Perskor, 1978), 89.

21. Horst Drechsler, Let Us Die Fighting: The Struggle of the Herero and Nama against German Imperialism (1884-1915), trans. Bernd Zöllner (London: Zed Press, 1980).

22. Philip Prein, "Guns and Top Hats: African Resistance in German South West Africa, 1907-1915," Journal of Southern African Studies 20 (1994): 99-121, 103.

23. Lewis Gann and Peter Duignan, The Rulers of German Africa (Stanford, CA: Stanford University Press, 1977), 277.

24. Ibid., 241.

25. Moritz Bonn, "German Colonial Policy," United Empire 5, 2 (1914): 129.

26. Stals, Kurt Streitwolf, 102.

27. Ernst L.P.Stals, "Duits Suidwes-Afrika na die Groot Opstande," Archives Yearbook for South African History 46 (1984): 1-154, 43.

28. See, e.g., Helmut Bley, South-West Africa under German Rule, 1895-1914 (Evanston, IL: Northwestern University Press, 1971), 170-73. 
29. “Eingebornen-Verordnungen," Windhuker Nachtrichten, 19 September 1907, 1.

30. Deutsche Südwest Zeitung, 25 November 1908.

31. G.P.Kruger, Outjo (undated mimeograph, National Library of Namibia).

32. Zimmerer and Zeller, Völkermord in Deutsch-Südwestafrika, 36.

33. Stals, "Duits Suidwes-Afrika," 66.

34. Gordon, Bushman Myth, 201-2.

35. Hans Rafalski, Vom Niemanssland zum Ordnungstaat (Berlin: Werseitz, 1930), 72; Dieckmann, Hai / / om in the Etosha Region, 91.

36. Stals, "Duits Suidwes-Afrika," 83.

37. Südwest-Zeitung, 17 October 1911.

38. Deutsche Kolonialzeitung 28 (1911): 773.

39. Deutsche Kolonialzeitung 29 (1912): 554; NAN, ZBU 2043, District Secretary to Governor (7 September 1913) [Link letter].

40. Gann and Duignan, Rulers of German Africa 142-43; Stals, "Duits Suidwes Afrika."

41. NAN, ZBU 2043, Verordnung J.nr 26883/5391 (24 October 1911; emphasis added).

42. Helen Fein, Genocide: A Sociological Perspective (London: Sage, 1993).

43. Stals, "Duits Suidwes-Afrika," 74, 84.

44. Deutsch Südwest-Afrika Zeitung, 27 April 1912, 1.

45. Cited by K.F.Budack, "Die Voelker Suedwestafrikas (21)," Allgemeine Zeitung, 10 October 1980, n.p.

46. NAN, ZBU 2043 Buschleute Specialia, Governor to District Head, Outjo (20 January 1913).

47. NAN, ZBU 2043 Letters, District Head, Outjo, to Governor (22 February 1913, 21 May 1914); Stals, "Duits Suidwes-Afrika," 85.

48. Deutsche Kolonialzeitung 1913: 672-3.

49. NAN, ZBU 2043, Link Ref 644 (7 September 1913).

50. He was being unduly modest: archival records show that he had also killed a Bushman in March 1913 and then, on 20 August, had shot both two Bushmen (a man and a woman). NAN, R. v. Thomas (1917) SCW, 6; Link letter (7 September 1913).

51. NAN, ZBU 2043, K. Boehme to Imperial Government (4 February 1915).

52. NAN, R. v. Becker (1979) SCW; Silvester and Gewald, Words Cannot Be Found, 311-12.

53. Stals, "Duits Suidwes-Afrika," 46-47.

54. NAN, BSW 1/1/81 G35, ZBU 2043 (15 September 1913).

55. David Harvey, The New Imperialism (New York: Oxford University Press, 2005). For readers unfamiliar with primitive accumulation, Harvey mentions that it includes

the commoditization and privatization of land and the forceful expulsion of peasant populations; conversion of various forms of property rights (common, collective, state, etc.) into exclusive private property rights; suppression of rights to the commons; commoditization of labor power and the suppression of alternative (indigenous) forms of production and consumption; colonial, neo-colonial and imperial processes of appropriation of assets (including natural resources); monetization of exchange and taxation (particularly of land); slave trade; and usury, the national debt and ultimately the credit system as radical means of primitive accumulation. The state, with its monopoly of violence and definitions of legality, plays a crucial role in both backing and promoting these processes. (145)

56. Max Weber, The Protestant Ethic and the Spirit of Capitalism, trans. Talcott Parsons (New York: Scribner, 1958), 121.

57. E.g., Alison Palmer, Colonial Genocide (London: C. Hurst, 2000); A. Dirk Moses, "Genocide and Settler Society in Australian History," in Genocide and Settler Society: Frontier Violence and Stolen Children in Australian History, ed. A. Dirk Moses, 3-48 (New York: Berghahn Books, 2004); Jürgen Zimmerer, "Colonialism and the Holocaust: Towards an Archaeology of Genocide," in Genocide and Settler Society: Frontier Violence and Stolen Children in Australian History, ed. A. Dirk Moses, 49-76 (New York: Berghahn Books, 2004). 
58. Martha Mamozai, Herrenmenschen: Frauen im deutschen Kolonialismus (Hamburg: Rowoldt, 1989), 128.

59. Daniel Walther, Creating Germans Abroad (Athens: Ohio University Press, 2002), 58.

60. David Courtwright, Violent Land: Single Men and Social Disorder from the Frontier to the Inner City (Cambridge, MA: Harvard University Press, 1996).

61. Hugh Ridley, Images of Colonial Rule (New York: St. Martin's Press, 1983), 140-43.

62. Fred Cornell, The Glamour of Prospecting (London: Fisher-Unwin, 1921), 41.

63. Robert Gordon, "Prostitution in Namibia in Colonial Times," in "Whose Body is It?" Commercial Sex Work and the Law in Namibia, ed. Diane Hubbard, 47-60 (Windhoek: Legal Assistance Center, 2002); Brigitte Schmidt-Lauber, Die verkehrte Hautfarbe (Berlin: D. Reimer, 1998), 368.

64. NAN, ADM 13/26 (6 November 1915).

65. Silvester and Gewald, Words Cannot Be Found, 243.

66. Ibid., 244.

67. Robert Gordon, "Inside the Windhoek Lager: Liquor and Lust in Namibia," in Drugs, Labor and Colonial Expansion, ed. William Jankowiak and Dan Bradburd, 117-34 (Tucson: University of Arizona Press, 2003).

68. See, e.g., "Die Schädelichkeitdes Alkoholgenusses in Südwest," Windhoek Nachtrichten, 28 October 1908; "Das Trunksüchtige Südwestafrika," Windhoek Nachtrichten, 17 April 1909.

69. Walther, Creating Germans Abroad, 97.

70. Mamozai, Herrenmenschen, 147-48.

71. Clara Brockmann, Brief eines deutschen Mädchens aus Südwest (Berlin: Mittler \& Sohn, 1912), 171.

72. Alexander Laban Hinton, ed., Genocide: An Anthropological Reader (Malden, MA: Blackwell, 2002), 14.

73. Bonn, "German Colonial Policy," 135.

74. Bonn, Wandering Scholar, 135.

75. Gann and Duignan, Rulers of German Africa, 104-36.

76. Bonn, Wandering Scholar, 138.

77. Courtwright, Violent Land, 174.

78. Walbaum, "Kriegstagebuch," 38.

79. Jan-Bart Gewald, Herero Heroes: A Socio-political History of the Herero of Namibia, 1890-1923 (Athens: Ohio University Press, 1999); Isobel V. Hull, "Military Culture and the Production of 'Final Solutions' in the Colonies: The Example of Wilhelminian Germany," in The Specter of Genocide: Mass Murder in Historical Perspective, ed. Robert Gellately and Ben Kiernan, 141-62 (New York: Cambridge University Press, 2003), 151.

80. Robert J.Gordon, "Vagrancy, Law and 'Shadow Knowledge': Internal Pacification 1915-1939," in Namibia under South African Rule: Mobility and Containment, ed. Patricia Hayes, Jeremy Silvester, Marion Wallace, and Wolfram Hartmann, 51-77 (Oxford: James Currey, 1998).

81. NAN, SWAA 2/14/2 Native Affairs, Memoranda and Reports 1916. Paranoia about Bushmen has a long history, extending up to the current period; see Gordon, Bushman Myth.

82. Gann and Duignan, Rulers of German Africa, 122-23.

83. German African Possessions (Late) No. 114: German Treatment of Natives (London: HMSO, 120), 2-3.

84. Bonn, Wandering Scholar, 134, 138.

85. Quoted in G.T. Schenck, "German South West Africa" (PhD diss., New York University, 1974), 138.

86. Gann and Duignan, Rulers of German Africa, 88.

87. A. Winifred Hoernle, Trails in the Thirstland: The Anthropological Field Diaries of Winifred Hoernle, ed. Peter Carstens, Gerald Klinghardt, and Martin West 
(Cape Town: Center for African Studies, University of Cape Town, 1987), 44; Ridley, Images of Colonial Rule, 152.

88. See, e.g., Wolfram Hartmann, ed. Hues between Black and White (Windhoek: Out of Africa, 2005).

89. Bley, South-West Africa under German Rule, 63-65.

90. Walther, Creating Germans Abroad; Paul Barth, Südwest-Afrika (Windhoek: John Meinert, 1926); Lora Wildenthal, German Women for Empire, 1884-1945 (Durham, NC: Duke University Press, 2001).

91. Albert Memmi, The Colonizer and the Colonized (Boston: Beacon Press, 1967), 101.

92. Erving Goffman, The Presentation of Self in Everyday Life (New York: Anchor, 1959), 80-81. I have dealt extensively with the ceremonial nature of vagrancy legislation during the mandate period in Gordon, "Vagrancy, Law and Shadow Knowledge"; the argument is even more applicable in the German colonial case.

93. Habermas uses this term to refer to the decisionistic aspect of the law, its origins in the will of the sovereign, and the fact that compliance with the law is externally motivated by the threat of sanctions. Jürgen Habermas, Between Facts and Norms: Contributions to a Discourse Theory of Law and Democracy, trans. William Rehg (Cambridge: Polity Press, 1996), 29.

94. Vincent Crapanzano, Waiting: The Whites in South Africa (New York: Doubleday, 1985).

95. Bley, South-West Africa under German Rule, 172.

96. Giorgio Agamben, State of Exception, trans. Kevin Attell (Chicago: University of Chicago Press, 2005).

97. W. Mattenklodt, Fugitive in the Jungle (Boston: Little, Brown, 1931); Otto Reiner, Achtzehn Jahre Farmer in Afrika (Leipzig: Paul List Verlag, 1924).

98. Harry M. Schwirck, "Violence, Race and the Law in German South West Africa 1884-1914" (PhD diss., Cornell University, Ithaca, NY, 1998).

99. Quoted in M.J. Olivier, "Inboorlingbeleid en -Administrasie in die Maandaatgebied van Suidwes-Afrika" (DPhil diss., Stellenbosch University, South Africa, 1961), 223.

100. Bley, South-West Africa under German Rule, 260-67; Schwirck, "Violence, Race and the Law," 172.

101. Schwirck, "Violence, Race and the Law," 233.

102. Bley, South-West Africa under German Rule, 198, 227.

103. NAN, ZBU 2043, Memorandum of Dr. Seibert (24 August 1911). In the policy discussions, it is remarkable how officials referred to historical precedent, especially in North America and the Cape Colony, then also cited academics to justify their choices.

104. NAN, ZBU 2043 (2 December 1911); emphasis added.

105. Professor von Luschanmade this suggestion during the 1906 joint meeting of the South African and British Associations for the Advancement of Science.

106. Deutsche Kolonialzeitung 1908: 99.

107. Lt. P. Gentz, "Die Buschmänner: Ein auststerbendes Volk in Deutsch-Südwestafrika," Deutsche Kolonialzeitung 26 (1909): 450-52.

108. Mathias Guenther, ed., Kalahari and Namib Bushmen in German South West Africa: Ethnographic Reports by Colonial Soldiers and Settlers (Cologne: Rüdiger Köppe, 2005), 214.

109. Deutsche Südwest-Afrika Zeitung, 16 July 1912; Oswin Köhler, "Dokumente zur Enstehung des Buschmannsproblemes in Südwestafrika," Afrikanischer Heimatkalender (1957): 54-62.

110. Siegfried Passarge, Die Buschmänner der Kalahari (Berlin: Reimer, 1907), 2.

111. Ibid., 124, 132 (emphasis added).

112. The information in this paragraph is drawn from documents in the National Archives of Namibia.

113. Leonard Schultze, Aus Namaland und Kalahari (Jena: Fischer, 1907).

114. Leonard Schultze, Zur kenntnis des Körpers der Hottentotten und Buschmänner (Jena: Fischer, 1928), 211. 
115. Leonard Schultze, "Südwestafrika," in Das Deutsche Kolonialreich, ed. Hans Meyer, vol. 2, 129-298 (Leipzig: Verlag des Bibliographischen Instituts, 1914), 295 (emphasis added).

116. Ibid., 290.

117. Rohrbach, German World Policies, 135.

118. NAN, ZBU 4032 (3 January 1912).

119. George McCall Theal, Ethnography and Condition of Africa South of the Zambesi before 1505 (London: Allen \& Unwin, 1919), 76.

120. Details in Robert Gordon, "The Rise of the Bushman Penis: Germans, Genitalia and Genocide," African Studies 57 (1998): 27-54.

121. Quoted in Foreign Office Historical Section, German African Possessions (Late) (London: HMSO, 1920; reprint, New York: Greenwood, 1969), 46.

122. NAN, ZBU 2043, unsigned rough draft, Governor to Colonial Secretary, Berlin (September 1913); see also Fritz Müller, Kolonien unter der Peitsche (Berlin: Rutten \& Loening, 1962), 169.

123. Robert Gordon, Picturing Bushmen: The Denver African Expedition of 1925 (Athens: Ohio University Press, 1997), 165.

124. Franz Seiner, "Die Buschmanngefahr in Deutsch-Südwestafrika," Deutsche Kolonialzeitung (1912): 311-12; "Die Buschmannfrage im nordlichen Deutsch-

Südwestafrika," Deutsche Kolonialzeitung (1913): 745-46.

125. I have dealt extensively with this penile fixation and the subsequent rather right-wing careers of all the German scholars involved in this "debate" in Gordon, "The Rise of the Bushman Penis." See also NAN, ZBU 1006.

126. NAN, B53/12 Seiner v. Kindt, GW 556 (1911).

127. Patrick Wolfe, "Settler Colonialism and the Elimination of the Native," Journal of Genocide Research 8 (2006): 387-409.

128. J.H. Wellington, South West Africa and Its Human Issues (Cape Town: Oxford University Press, 1967), 43.

129. Quoted in Silvester and Gewald, Words Cannot Be Found, 240.

130. Hull, "Military Culture," 160.

131. Bundesarchiv Koblenz, Nachlass Moritz Bonn, N.1082, vol. 13b "The End of the Colonial Discussion" (undated and unpaginated manuscript; emphasis added).

132. In 1909 Bonn had already argued that "as long as there are still people who deem such policies as necessitated by Nature, the danger will persist that they may also be used in other places. If the mistakes of Trotha's colonial policy can be surrounded with a theoretical halo, nothing will protect from it being repeated." Quoted in Volker Berghahn, Europe in the Era of the Two World Wars (Princeton, NJ: Princeton University Press, 2006), 25. It is also of interest that the figures Bonn gives for indigenous losses during the war are considerably lower than those given by other sources. Before the war he put the population at about 100,000, and after the war at 87,796 (but including some 10,500 Owambo). Bonn, "German Colonial Policy," 128, 129.

133. Rohrbach, German World Policies, 152.

134. Ibid., 137.

135. Bley, South West Africa under German Rule, 230, 226.

136. Paul Rohrbach, Deutsche Kolonialwirtschaft. Band 1: Südwest-Afrika (Berlin: Buchverlag der "Hilfe"), 352.

137. Gustav Frenssen, Peter Mohr's Fahrt nach Südwest Afrika (Berlin: G. Grote, 1906), 198.

138. As a possible topic for future investigation, one could go further and suggest that Hannah Arendt's well-known thesis that the origins of German totalitarianism can be found in the colonial experience can be further qualified. Its cultural roots lay not so much in relations between Germans and blacks as in relations between Germans and Bushmen. It is no accident that, in the documents preserved in the National Archives of Namibia, German officials invariably distinguish between vagabundieren Buschleute and Eingeborenen ("vagabond Bushmen" and "Indigenes"). It is striking how much effort-both administrative and emotional—colonizers invested in controlling people of no fixed 
address: vagabonds, vagrants, Bushmen, and the like. My reading of the literature on the Nazi state suggests an obsession with the control of movement. The parallels and, indeed, continuity between the "Wandering" Jews, the Gypsies, and the Bushman "vagabonds" are important not only for the alleged mobility of these groups but also for their attributed attitudes toward property.

139. Perhaps the most telling example in this regard is Afrikaans journalist E.N. Marais's interview of the Herero leader Samuel Maharero after the infamous Battle of Waterberg. Marais's sympathetic account, "Die Woestynvlug van die Hereros," in Versamelde Werke (Cape Town: Human and Rousseau, 2006), presents one of the few first-hand Herero accounts of that battle. In this accounting, Samuel Maharero realized that he could never match the Germans in terms of technology and thus resolved to entice them into the desert, where Herero were better experienced. Unfortunately his followers refused to leave their cattle, with disastrous consequences.

140. Prein, "Guns and Top Hats," 109.

141. Stals, Kurt Steinwolf, 110.

142. Palmer, Colonial Genocide.

143. Malvern van Wyk Smith, "Metadiscourses of Post Colonialism: 'Strong Others' and European Images of Africa," History and Anthropology 9 (1992): 267-97. These two groups also happen to be those most geographically distant from Europe.

144. Zimmerer, "Colonialism and the Holocaust."

145. Georg P.J.Trümpelmann, Die Boer in Suidwes-Afrika, Archives Yearbook for South African History 2 (1948).

146. Quoted in Hedley Chilvers, The Seven Wonders of Southern Africa (Johannesburg: SAR \& $\mathrm{H}, 1929), 276$.

147. Gordon, "The Rise of the Bushman Penis," 59-61.

148. Sara Pienaar, South Africa and International Relations between the Two World Wars (Johannesburg: Witwatersrand University Press, 1987). 